\title{
Halacaropsis hirsuta (Acari: Halacaridae)'nın Türkiye Faunası İçin İlk Kaydı
}

\section{Furkan DURUCAN ${ }^{1 *}$, Yunus Ömer BOYACI ${ }^{2}$}

${ }^{1}$ Süleyman Demirel Üniversitesi, Fen Bilimleri Enstitüsü, Isparta

${ }^{2}$ Süleyman Demirel Üniversitesi, Eğirdir Su Ürünleri Fakültesi, Isparta

$$
\text { Geliş: } \quad 14.12 .2015
$$

Kabul: $\quad 18.02 .2016$

*Sorumlu yazar: e-posta: f_durucan@hotmail.com

Bas1l1 ISSN: 1300 - 4891E. Dergi ISSN: 1308 - 7517

\section{Özet}

Deniz halacaridlerinden Halacaropsis (Bartsch, 1996) cinsi, Akdeniz, Güney Afrika, Kuzey Atlantik ve Avusturalya'dan olmak üzere 5 tür ile temsil edilmektedir. Bu çalışmada, Halacaropsis hirsuta (Trouessart, 1889) türü, Marmara Denizi'nin kuzey kayalık kıyllarında, 3-4 m.'de bulunan Ulva lactuca (Linnaeus, 1753) algleri arasından toplanmıştır. Bu tür aynı zamanda, Halacaropsis cinsininde Türkiye'den ilk kaydıdır.

Anahtar kelimeler: Halacaropsis hirsuta, Acari, yeni kayit, Ulva lactuca, Marmara Denizi

Halacaropsis hirsuta (Acari: Halacaridae): First Record for the Turkish Fauna

\begin{abstract}
The marine halacarid mite genus Halacaropsis (Bartsch, 1996) currently represented five species from the Mediterranean, southern Africa, northern Atlantic, and Australia. A new record, Halacaropsis hirsuta (Trouessart, 1889) was collected among Ulva lactuca (Linnaeus, 1753) algae (3-4 m depth off) from the rocky shores of northern coast of Marmara Sea. This is the first record of the genus Halacaropsis from Turkey.
\end{abstract}

Keywords: Halacaropsis hirsuta, Acari, new record, Marmara Sea, Ulva lactuca

\section{INTRODUCTION}

Halacarid mites are meiobenthic organisms which can be found not only in intertidal zone but also in the subtidal zone down to the deep ocean at depths of $7000 \mathrm{~m}$. Halacarids are present in all oceans and on all continents. They generally live in submerged habitats. Halacarid mites live in a variety of substrata: bryozoans, in and on colonies of sponges, within tufts of macroalgae and seagrass, on large fronds, mussels, hydrozoans, barnacles, polychaetes, flocculentooze, amongst surface structure sand gill filaments of crustaceans and molluscs, and between spines and in the gut of echinoderms. The small body size of mites has enabled them to contribute several independent subgroups to the meiobenthos. The first record of a mite from sea shore was published more than 200 years ago. Since then, more than 1100 species of marine mite have been described from all over the world. Some few species suspected to be parasites. Halacarids may be infested by epizoa (suctorians, peritrichciliates) and epiphyta (unicellular green algae and diatoms). In halacarid carcasses have fungi colonized the mites after their death (Green \& Macquitty, 1987; Bartsch,1989; 2004a; 2006; Giere, 2009).

In Turkey, the first studies carried out by German researcher Dr. Ilse Bartsch who gave 18 new halacarid records from the province of Sinop coasts (Bartsch, 2001, Bartsch, 2004b; Bartsch, 2013). 
In this paper we report Halacaropsis hirsuta (Trouessart,1889) from Marmara Sea, Turkey (Fig.1). This is the first record of this species from Turkey. The genus is Halacaropsis (Bartsch, 1996) also reported here for the first time from Turkey.

\title{
MATERIALS and METHODS
}

Bostanc1 Beach (Istanbul), on the Marmara Sea, at about $\left(40^{\circ} 58^{\prime} \mathrm{N}, 29^{\circ} 03^{\prime} \mathrm{E}\right) \mathrm{NE}$, sublittoral rocky shore, among Ulva lactuca (Linnaeus, 1753) algae, 3-4 m. three deutonymphs. Specimens were collected by hand netting then sorted in the laboratory with the aid of a stereo microscope. The collected specimens were washed with a strong jet of water in a $1 \mathrm{~mm}$ mesh sieve over a $100 \mu \mathrm{m}$ sieve, were cleared lactic acid. The following abbreviations are used in the text: ds1-6, dorsal setae 1-6 on idiosoma; AE, anterior epimeral plate; PE, posterior epimeral plate; GA, genito anal plate.

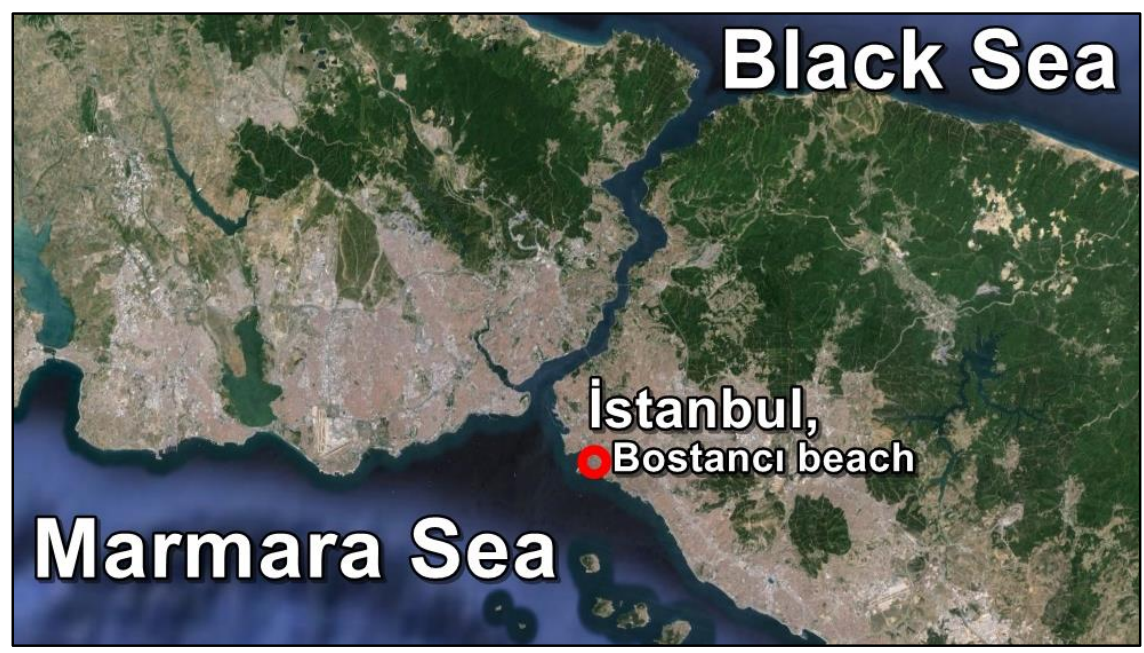

Figure 1. Map of the study area showing the sampling station

\section{RESULT and DISCUSSION}

\author{
Systematics \\ Class ARACHNIDA Cuvier, 1812 \\ Subclass ACARI Leach, 1817 \\ Family HALACARIDAE Murray, 1877 \\ Genus HALACAROPSIS Bartsch, 1996 \\ Halacaropsis hirsuta Trouessart, 1889
}

Dorsum with 6 pairs of idiosomatic setae; ds-2, ds-3 and ds-4 generally enlarged. AE with 3 pairs of ventral setae. PE with 1 dorsal and 3 ventral setae. Deutonymph GA with 56 pairs of perigenital setae and 4-5 pairs of subgenital setae. Halacaropsis's shape of leg I enlarged with long and longer and wider than following legs (Trouessart, 1889; André, 
1946; Bartsch, 1996; Bartsch, 2006). H.hirsuta, a species described by Trouessart, 1889. Our specimens general morphology accord with André's specimens (André, 1946).

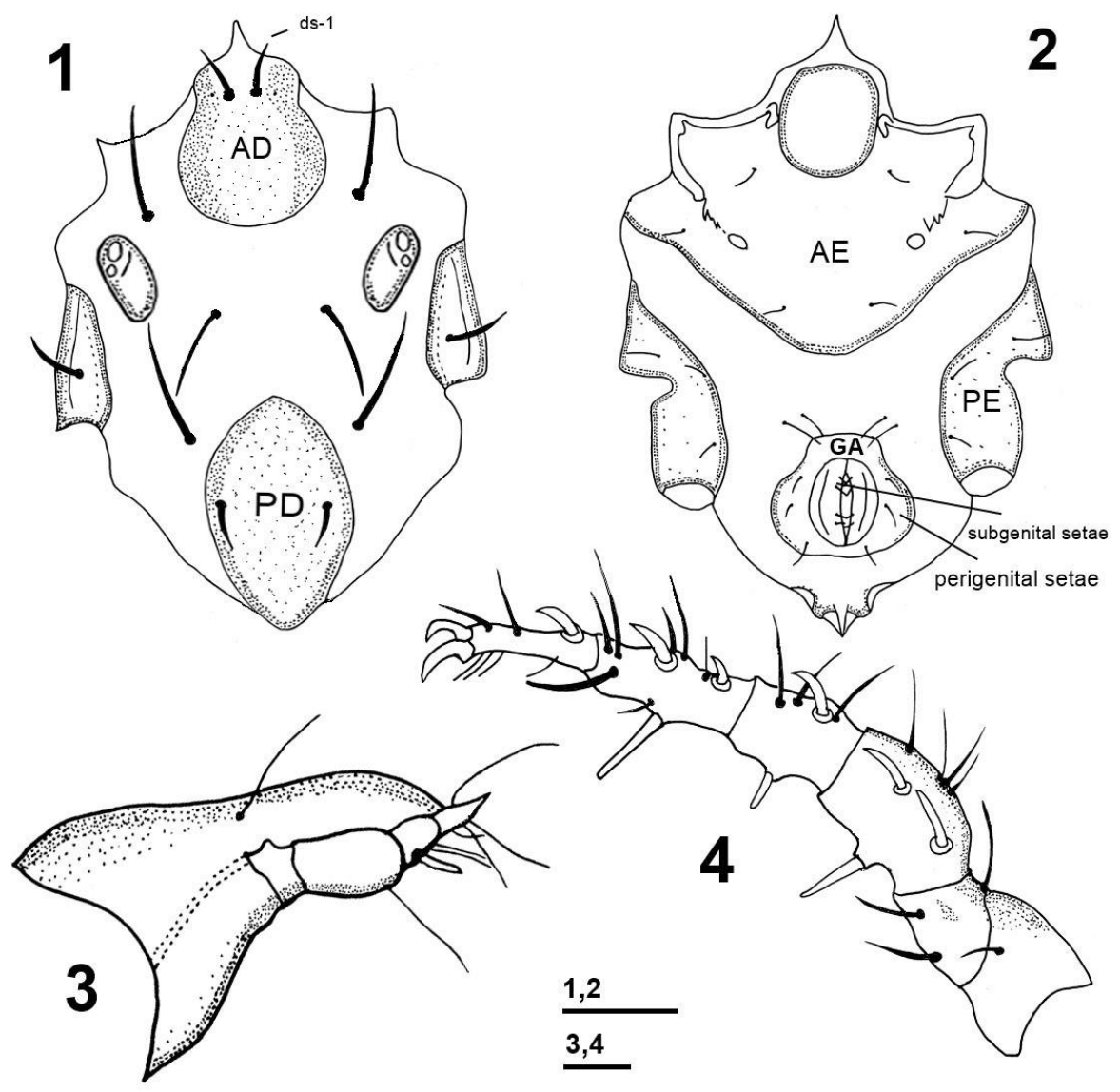

Figure 2. Halacaropsis hirsuta Trouessart, 1889, deutonymph. 1. Idiosoma dorsal; 2. Idiosoma ventral; 3. Gnathosoma, lateral; 4. Leg I, lateral. Scale Bars: 1,2 $=100 \mu \mathrm{m}, 3,4=50 \mu \mathrm{m}$

\section{How to Cite}

Durucan F., Boyacı Y. Ö.. 2016. Halacaropsis hirsuta (Acari: Halacaridae)'nın Türkiye Faunası İçin İlk Kaydı. Eğirdir Su Ürünleri Fakültesi Dergisi. 12(1), 37-40.

\section{REFERENCES}

André, M., 1946. Halacariens Marins. Faune de France 46, 1-152p.

Bartsch, I., 1989. Marine Mites (Halacaroidea: Acari): a geographical and ecological survey. Hydrobiologia 178,21 - 42p.

Bartsch, I., 1996. Halacarines (Acari: Halacaridae) from Rottnest Island, Western Australia: the general Agauopsis Viets and Halacaropsis gen.nov., Records of the Western Australian Museum 18, $1-18 \mathrm{p}$.

Bartsch, I., 2001. Black sea Copidognathinae (Arachnida, Acari, Halacaridae): A review, Mitt. Mus. Nat.kd. Berl., Zool. Reihe 77 (2), 247 - 275p. 
Bartsch, I., 2004a. Geographical and ecological distrubition of marine halacarid general and species (Acari: Halacaridae), Experimental and Applied Acarology, 34, 37 - 58p.

Bartsch, I., 2004b. The Black Sea halacarid fauna (Halacaridae, Acari): faunal comparison with the Mediterranean, Eastern North Atlantic, North Sea, and Baltic and reflection on its origin, Mitt. Mus. Nat.kd. Berl., Zool. Reihe 80 (2), 143 - 158p.

Bartsch, I., 2006. Halacaroidea (Acari): A Guide to Marine Genera, Organisms Diversity and Evolution 6, Electr. Suppl. 6, 1-104p.

Bartsch, I., 2013. New species and records of halacarid mites (Halacaridae: Acari) from the Black Sea. Entomol. Mitt. Zool. Mus. Hamburg 16 (189): 69-85

Giere, O., 2009. Meiobenthology: The Microscopic Motile Fauna of Aquatic Sediments. SpringerVerlag, Berlin Heidelberg, Germany. 527 pp.

Green, J.,Macquitty, M., 1987. Halacarid Mites (Arachnida: Acari) Keys and notes for t he identification of the species, Synopses of the British Fauna, ed: Kermak, D.M. and Barnes, R.S.K. No:36, The Linnean Society, London. 178 p.

Trouessart, E., 1889. D'acariens marins (Halacaridae) des cotes de France. Diagnosed'especes et genres nouveaux. Naturaliste 11, 181p. 